\title{
Understanding Bird Preference on Agroforestry System: Is There a Potential Case for Birdwatching Development?
}

\author{
Agung Sih Kurnianto ${ }^{1 *}$, Jati Batoro², Nia Kurniawan ${ }^{2}$ \\ ${ }^{1}$ Graduate School of Environment Sciences, University of Brawijaya, Malang, Indonesia \\ ${ }^{2}$ Department of Biology, Faculty of Mathematics and Natural Sciences, University of Brawijaya, Malang, Indonesia
}

\begin{abstract}
The main objective of this study is to understand the bird preference on the different types of agroforestry management and the implication on the development of birdwatching as a potential ecotourism. The study was conducted at the agroforestry area of Gubugklakah Village, Malang Regency, East Java Province, Indonesia, from May to November 2016. Five observation sites were chosen: 1) agroforestry developed by ethno-conserving system; 2) agroforestry close to the national park; 3) agroforestry; 4) conventional agriculture area; and 5) houses area. Point Count was applied in this study by determining 5 sampling sites that separated 100-150 m. Survey was conducted once a week and observed every 15 minutes from 6.00 to $9.00 \mathrm{am}$. The species of bird that observed and heard were noted, identified and result of the field identification was stored in field book. The result shows that the highest Importance Value Index (IVI) was presented by Cave swiftlet and some species that specialized in farmland. Agroforestry area was showing more potential as the birdwatching spot compared to conventional agriculture area and houses area. In addition, agroforestry area showing a high Value of Interest (VOI) that represented a nativity on the birds settler and made it to be the suitable area for birdwatching activities.
\end{abstract}

Keywords: agroforestry, birdwatching, management, preference.

\section{INTRODUCTION}

Birdwatching is one of the most developed ecotourism activity in the world. It is the second popular outdoor tourism in USA that has an amazing development and unexpectedly contributes a great potential for the national economic development. The average revenue generated from birdwatching tourism reaches more than 50.000 USD per year [1]. In addition, other sector, such as transportation, is also predicted to be affected by this activity by reaching 7.6 billion USD. The annual economic benefit of five major birding locations in USA is estimated to reach up to 2.4-40 million USD [2]. Birdwatching could also escalate the species value, as estimated by Munn [3] that each of macaw bird in south Peru could obtain 22.500 to 165.000 USD for its lifetime. In addition, birdwatching offers profitable results both in the conservation and people perspective towards the birds. However, the utilization of bird diversity through birdwatching tourism is still not wellimplemented in Indonesia compared to hunting and trading activities as a long term utilization that is not conservative. These facts urge the bird

\footnotetext{
${ }^{*}$ Correspondence address:

Agung Sih Kurnianto

Email : agung.sih.kurnianto@gmail.com

Address : Graduate School, University of Brawijaya, Mayjen Haryono 169, Malang 65145
}

diversity in Indonesia to be a permanent extinction for a long term period [4].

On the other hand, the expansion of urban and agriculture area in Indonesia by forest clearing is directly threaten the birds, including its diversity [5], regeneration, feed availability, and daily activities $[6,7]$. The agroforestry system has long been known as an original Indonesian agriculture that concerned and emphasized the continuity of agriculture and forestry aspects. According to economical view, agroforestry system is firm, easy to adapt with the nature, competitive, and provides $80 \%$ of village revenue [8]. Agroforestry system has better conservation impact on the fauna diversity compared to agriculture system and monoculture forestry. As the multi-habitat landscape, agroforestry plays an important role on mini-ecosystem for some fauna, such as mammals, birds, reptiles, and invertebrates [8]. As much as $60 \%$ of bird species with various ecosystem role lives on the agroforestry area [9]. Moreover, there is an interesting tendency in which the birds prefer to live on the transition region between farmland and primary forest as illustrated by agroforestry, compared to other area, such as monoculture forest and active farmland $[10,11]$.

The vegetation planted in agroforestry area consists of herbaceous plants and trees [9] that affected the diversity and visiting time of the 
birds [12]. We estimated that agroforestry system would provide habitat that is more dynamic than other artificial habitat, such as conventional agriculture or forest. An understanding on the distribution and variation of bird species is very important on supporting and developing birdwatching as one of the potential ecotourism, also maintaining the continuity of agroforestry system. Therefore, the main objective of this study is to reveal the bird preference based on agroforestry management and the implication on the potential development of birdwatching.

\section{RESEARCH METHOD}

\section{Study Area}

Research area was located at the agroforestry area on Gubugklakah village $\left(7^{\prime} 21^{\prime}-7^{\prime} 31^{\prime}\right.$ south latitude and 110'10'-111'40' east longitude), Malang regency, East Java province, Indonesia. Study was conducted on May to November, 2016. Five observation sites were chosen to represent three different habitats, including agroforestry, houses area, and conventional agriculture area. All site research was located in village managed by PT. Perhutani Persero in cooperation with local people. The determination of agroforestry area was based on 3 criteria: 1) Sacred by the local people (agroforestry developed by ethno-conserving system); 2) Located on the edge of national park; 3) Managed regularly. As comparison, we also observed two locations that represented nonagroforestry management: 1) Conventional agriculture area; and 2) Houses area. Conventional agriculture area was mainly planted by monoculture sugar cane plantations, while houses area was consisted of houses located in the same area (Fig. 1). Management area was illustrated by the classification into 4 vegetation types (Table1).

Table 1. Percentage of Vegetation Coverage on 5 Study Sites in Gubugklakah

\begin{tabular}{llllll}
\hline \multicolumn{1}{c}{ Classification } & \multicolumn{5}{c}{ Study Sites } \\
\cline { 2 - 6 } & $\mathbf{1}$ & $\mathbf{2}$ & $\mathbf{3}$ & $\mathbf{4}$ & $\mathbf{5}$ \\
\hline $\begin{array}{l}\text { Seedling } \\
\text { h: } 0-1.5 \mathrm{~m}\end{array}$ & $60 \%$ & $40 \%$ & $45 \%$ & $70 \%$ & $40 \%$ \\
$\begin{array}{l}\text { Sapling } \\
\text { h: } \geq 1.5\end{array}$ & & & & & \\
d: $10 \mathrm{~cm}$ & $25 \%$ & $45 \%$ & $35 \%$ & $10 \%$ & $30 \%$ \\
$\begin{array}{l}\text { Pole } \\
\text { d: } 10-20 \mathrm{~cm}\end{array}$ & $15 \%$ & $10 \%$ & $15 \%$ & $5 \%$ & $5 \%$ \\
$\begin{array}{l}\text { Tree } \\
\text { d: }>20 \mathrm{~cm}\end{array}$ & $0 \%$ & $5 \%$ & $5 \%$ & $15 \%$ & $25 \%$ \\
\hline
\end{tabular}

Notes: $\mathrm{h}=$ height; $\mathrm{d}=$ diameter; $1=$ conventional agriculture; 2 = houses area; 3 = agroforestry developed by ethno-conserving system; 4= agroforestry; 5= forest-nearagroforestry.

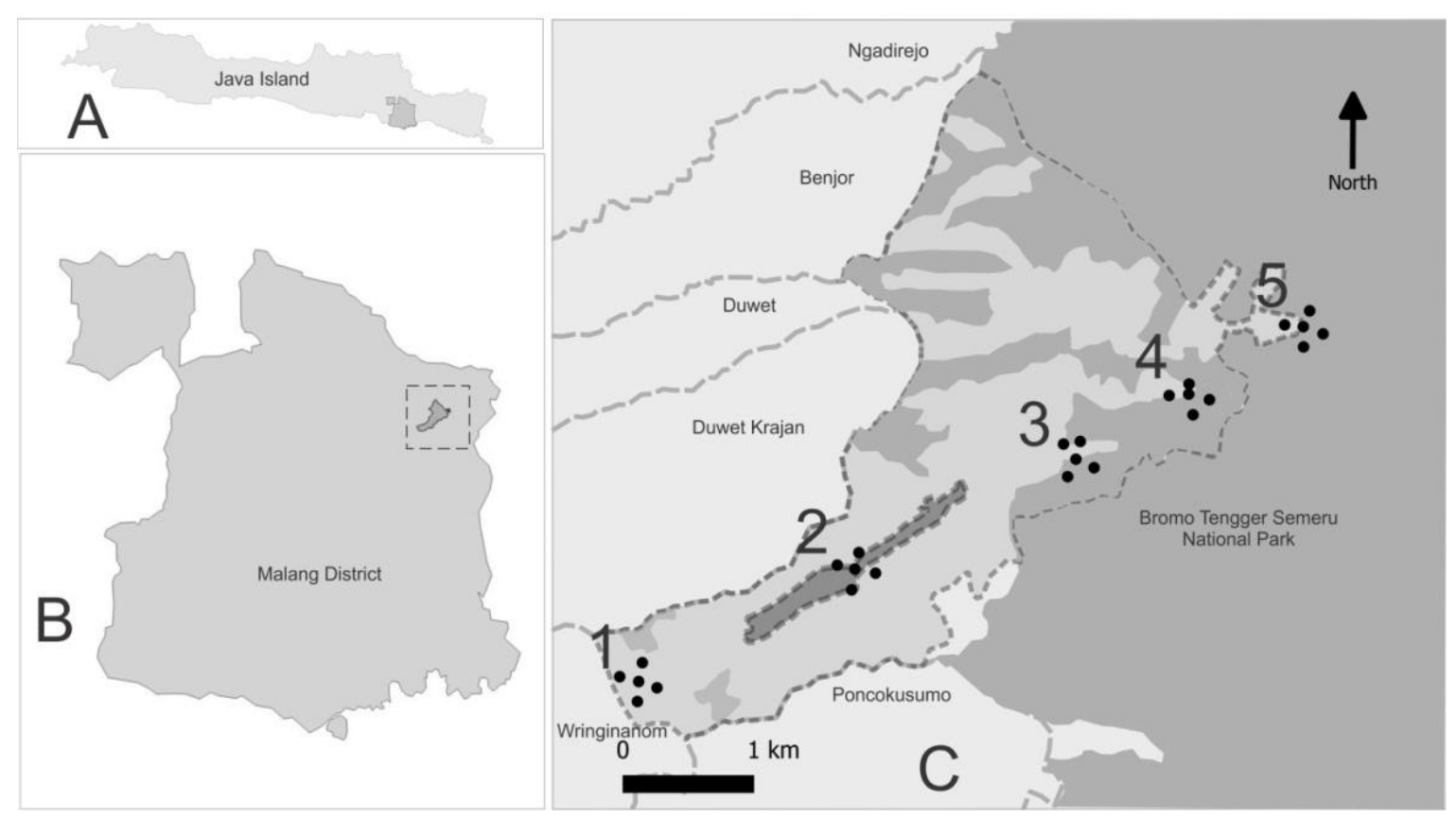

Figure 1. Map of Study Area in Gubugklakah

Description: Black circles show the site points. Number shows classification of sites. A= Java Island, one of Indonesian Archipelago; $\mathrm{B}=$ Malang District; $\mathrm{C}=$ Gubugklakah (grey and dashed line) with villages and forest around it; $1=$ Conventional agriculture (light grey); 2= Houses (dark grey and dashed line); 3= Agroforestry with ethno-conserving system; 4= Agroforestry; $5=$ Forest-near-agroforest. All dark grey inside the Gubugklakah border indicates agroforestry system. Land use and borders were based on Spatial Development Plans map 2016, Office of Public Works and Area Spatial, Malang Regency. 


\section{Bird Survey and Vegetation Approach}

We applied curve point method on this study. Each survey location was selected 5 point sites $(r=20 \mathrm{~m})$ and separated 100-150 m between each point. Survey was conducted once a week for 15 minutes started from 06.00-09.00 am as the most active time for the bird activities, in May 2016 until January 2017 [13]. We recorded all birds that were observed or heard on each site. We avoided working during rainy, cloudy, windy, or foggy situation. Birds that have no contact with the vegetation on the Point Count, but observed during the survey, were classified as Flying Through (FT) and Flying Over (FO). We used Nikon Aculon A30 $8 \times 25$ binoculars to identify the bird species, digital camera Canon EOS $1100 \mathrm{D}+300 \mathrm{~mm}$ Canon lens to take the pictures, and Sony ICD-PX40 digital recorder to record the bird voice. We confirmed the bird voice by replaying and comparing the voice with the online database (http://xeno-canto.org).

Bird was observed on the multiple typevegetation. We classified the vegetation type that covered each site. Multiple type model on vegetation was estimated by: 1) Occupancyclassification, defined as possibilities for some certain species to live in each vegetation; and 2) Role of use, defined as possibilities for some species that was affected by specific plants.

\section{Data Analysis}

Total bird and bird species were analyzed descriptively by using Ms. Excel 2007 to formulize Importance Value Index (IVI). We evaluated the diversity and bird preference by using PAST software. Preference value for three study sites (conventional agriculture, houses, and agroforestry) was obtained by using bi plot analysis. We also designed the bird community as farmland and forest specialist according to the literature. Species that used to live in the forest (more than $50 \%$ of its lifetime) was categorized as forest bird. While species that used to live on the open vegetation (more than $50 \%$ of its lifetime), such as grass, agriculture area, and houses area, was categorized as farmland bird. Species that lives equally in two habitats, both in the forest and in the farmland, was categorized as generalist. The habitat type and tropic category were analyzed descriptively using Ms. Excel 2007.

We designed the bird community that represented in Value of Interest (VOI) as the birdwatching object with some certain range value (maximum value was 5 ). The valuation was formed by adding 1 point for each species that met the criteria as follows: 1) law protection [14]; 2) IUCN conservation status was categorized as threatened (Vulnerable, Endangered, Critically Endangered), or Near Threatened [15]; 3) CITES status [16]; 4) endemic in Indonesia [17]; and 5) value of the frequency of attendance. We classified the VOI in 5 ranges $=\mathrm{A}(4-5) ; \mathrm{B}(3-3.9)$; $C(2-2.9) ; D(1-1.9)$, and $E(0-0.9)$. We projected that the high VOI would represent an interesting object for birdwatching tourism that developed in agroforestry system.

\section{RESULT AND DISCUSSION Bird Observation}

We recorded 3783 individual consisted of 67 species, 35 families, and 25 sampling sites. As much as $39 \%$ species from total species included as general classification in its vertical distribution. The result represented that most of observed birds could adapt with the wide range of habitat conditions. On the other hand, $16 \%$ species from total species lives on seedling-sapling habitat. This species often found on farmland, houses, and agroforestry. As much as $11 \%$ species lives on big trees, where it only found in agroforestry and forest. The high value was represented in Fly-over category (approximately 34\%), including swiftlet and migratory birds (i.e. Sparrowhawk). Both of them fly in flocks. Sparrowhawk (Chinese Sparrowhawk Accipiter soloensis and Japanese Sparrowhawk Accipiter gularis) is an annual winter visitor [16]. Besides, Accipitridae was observed at FO condition, flew around in circles following the geothermal flow (soaring) [18].

Cave Swiftlet Callocalia linchi has the highest Important Value Index (IVI), 0.32 (Fig. 2). The result demonstrated that Cave Swiftlet takes an important role on the ecosystem of agroforestry in Gubugklakah. Cave Swiftlet usually forms flock, and often lives with other sympatric species. They usually visit the figs trees that fruitting [19]. Swiftlet still flies during the rain; this makes them different with other birds. In fact, rain would trigger insects to fly from the leaves of Ficus sp., and make Cave Swiftlet to be more concentrated [20]. During the bright weather, Cave Swiftlet flies low in circles within the open space above the agroforestry.

Sooty-headed bulbul Pycnonotus aurigaster was ranked on the second place for IVI (0.25). Most of their lives are spent in the agroforestry area [21]. Therefore, we estimated that Sootyheaded bulbul has adapted well with the availability of food in agroforestry area. 


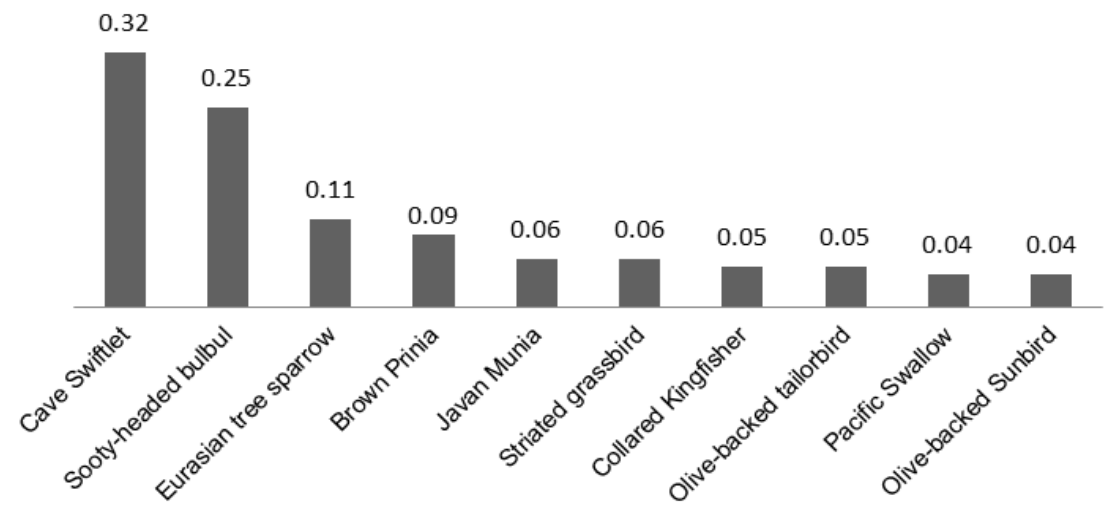

Figure 2. The Ten Highest IVI, Species IVI vary in 67 species (see Supplementary 1)

Thus, it was supported by its classification as omnivorous that has a wide range of food, including fruits and insects [17]. The beak is adapted to hunt insects from perch and the behavior to form flock makes them potential on controlling agricultural pest. Pycnonotus aurigaster is adapted to hunt in a flock that supported by vocal communication [20].

The fourth place of IVI rank was occupied by Brown Prinia Prinia polychroa, approximately 0.09. They belong to insectivores that lived in agricultural area [17]. On the other hand, the observation result shows a high IVI on Eurasian tree sparrow, a cosmopolitan species that adapted to live in human houses [17]. The other birds, such as Javan Munia, Striated Grassbird, Collared Kingfisher, Olive-backed Tailorbird, and Olive-backed sunbird, are easy to be found on the open space area, agriculture, and houses area. Another species, Pacific swallow, is recorded to be found in a large flock during the rainy season [17].

\section{Bird's Preference}

The observation shows that houses and agroforestry area have a high preference value for some certain species (Fig. 3). The houses area was inhabited by the population of Erasian tree sparrow Passer montanus that is known to be easily adapted with the human food [17]. Cave swiftlet is usually found in a large flock in the open space, such as conventional agriculture area and agroforestry area that applying ethnic conservation system. The basic of ethnicconserving system is sacred concept that respecting a tree (Ficus sp.) and graveyard area. Moreover, sacred area has long been known to take an important part on conserving the biodiversity around the world [22], and indirectly conserved the high diversity of birds.

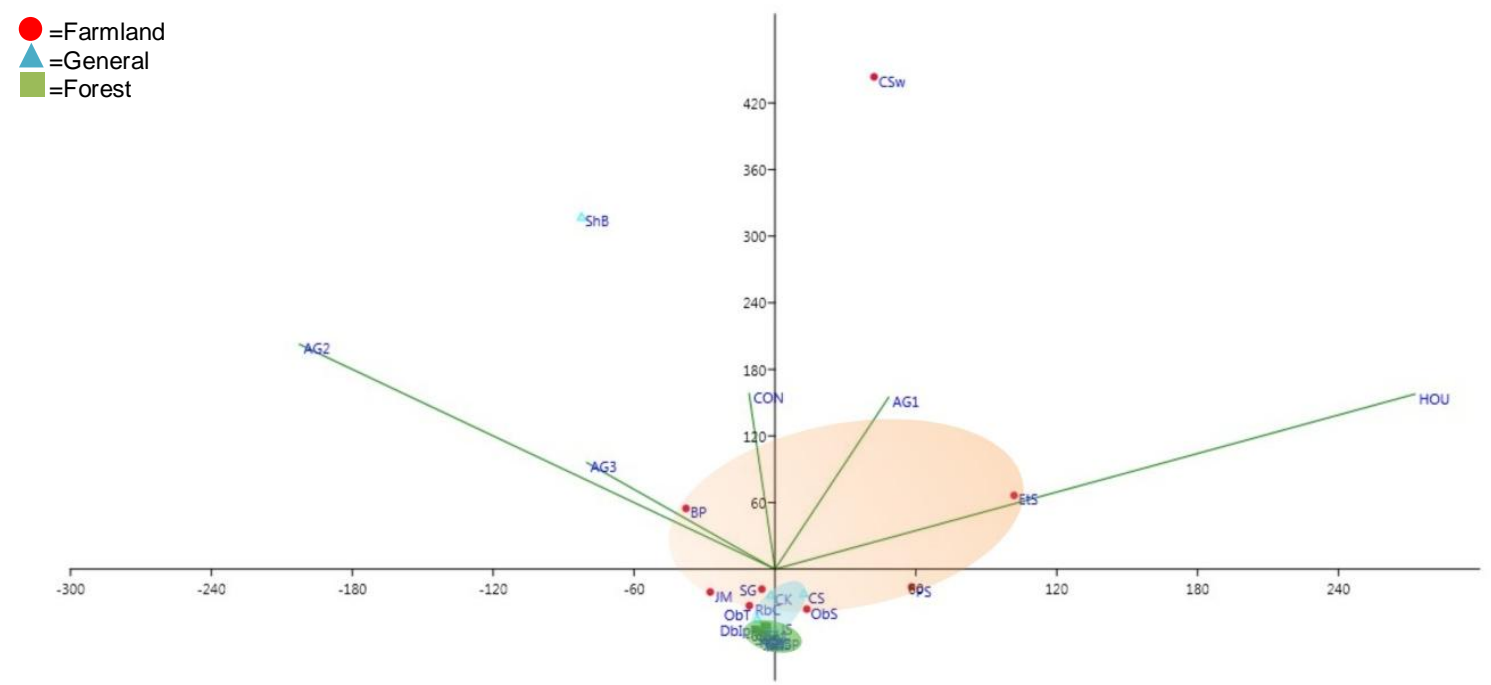

Figure 3. Biplot analysis bird number by point count versus 5 study sites

Description: Study sites are CON= conventional agriculture; HOU= houses; AG1= agroforestry with ethno-conserving system; AG2= agroforestry area; AG3=forest-near-agroforestry. Bird species are represented by their species code (see Supplementary $1)$. 
Conventional agriculture and agroforestry area were mostly visited by farmland birds that hunting insects, such as Sooty-headed Bulbul and Brown Prinia. Interestingly, the preference result illustrated that agroforestry area close to forest was usually visited by several species of birds with different habitat specialization, including farmland, forest, and general (Fig. 4 \& 5).

The management area plays an important role on the habitat preference of birds on Gubugklakah. According to Figure 4, almost all area supported the habitat expansion of farmland birds, although forest and generalist birds also found on those area. The fact that the agroforestry area close to natural forest was significantly affected the presence of three species of birds (specialized on the farmland, forest, and generalist), although the number of birds were higher in the agroforestry and other open space area. This presented the quality of bird that visited the agroforestry near the natural forest is much higher compared to the quantity itself. A significant improvement was occurred on the diversity of birds that presence in those area. In fact, the high diversity of bird is supported by
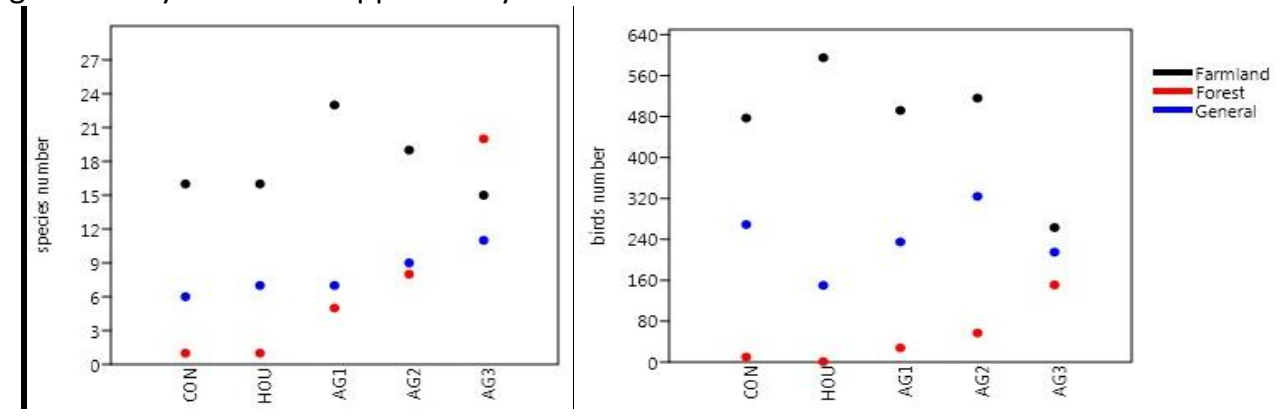

Figure 4.Species and Birds Number in Scatter Plot among 5 Study Sites

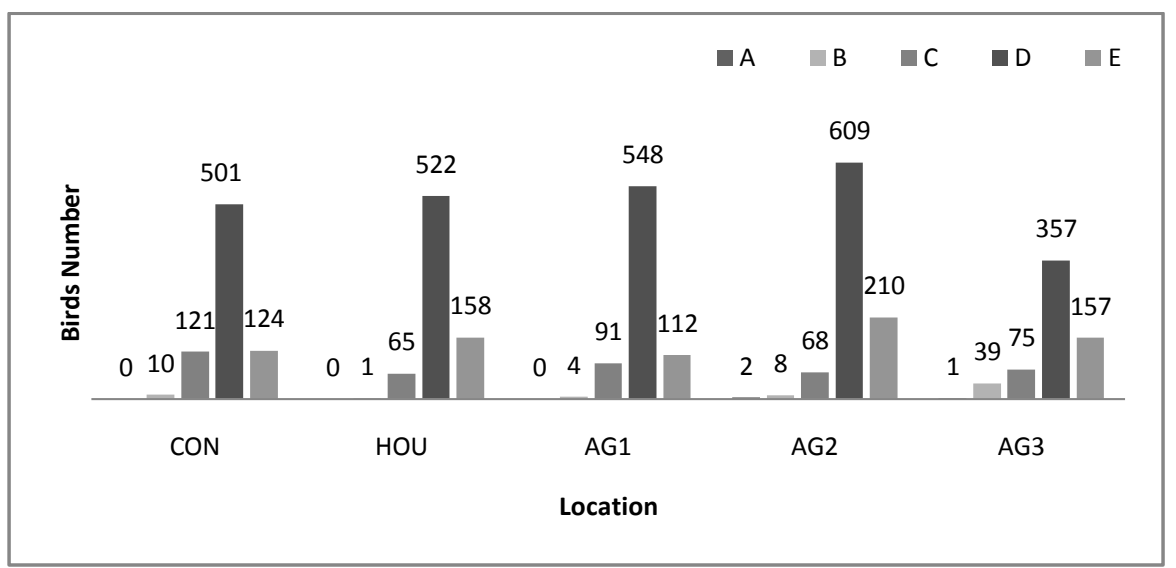

Figure 5. Variation in Bird Number among Study Sites and Classification Number Based on Value of Interest (VOI), a Multi Scale Law Protection, Threatened Status, CITES, Endemicity, and Frequency

Description: Habitat types of study sites included conventional agriculture (CON), houses (HOU), agroforestry with ethnoconservingsystem (AG1), agroforestry (AG2), and forest-near-agroforestry (AG3). $A(4-5)$; $B(3-3.9) ; C(2-2.9)$; $D(1-1.9)$, and $E(0-$ $0.9)$. 
Traditional agroforestry system is a way to reduce the threat on the wildlife. Perennials combined with the short-term corps provide a suitable habitat for birds to do various activities, such as breeding, nesting, and hunting $[8,20,26]$. Nevertheless, the important value of birds that lives in agroforestry area has a potential to increase more, especially if it supported by birdwatching ecotourism. However, the development of birdwatching needs to be supported by in-depth approach towards the potential sites and native species.

The in-depth approach can be reached from the development on the concept of management and conservation [26]. In line with our study, we suggest the provision of guidance contains of bird classification and some potential spots as a guide on identifying the birds during the activity of birdwatching. A high Value of Interest (VOI), ranging from 2 to 2.9 (C), on conventional agriculture and houses area is caused by the raptor migration track that crossing those area.

Migration track crossed by Chinese Sparrowhawk and Japan Sparrowhawk is very interesting to be observed during the migration season [17]. During those special migration seasons, the bird observers could watch hundreds of eagle in the same time. That view is supported by the area condition that is more open than the agroforestry area. Agroforestry area generally has higher VOI than two other areas. In contrary with the conventional agriculture and houses area, agroforestry area has more species and higher number of birds that belong as native species. It is important to notice that case in order to maximize and develop the potential of birdwatching area that does not affected by the migration season. According to figure 4, the habitat contrast between natural forest and agroforestry invites more native birds to live in those area, such as Javan Hawk Eagle Nisaetus bartelsi that is endemic to Java. Agroforestry area combines the perennial habitat that tend to shade and consists of vegetables [12].The high tree is suitable for Javan Hawk Eagle to perch and hunt its prey, such as rodentia among the vegetable farm.

Although it only has fewer quantity compares to other agroforestry area, it has a balance $B$ and $C$, and also A criteria of $\mathrm{VOI}$, that represented its capability on supporting the life of native species.

Agroforestry area, both ethnic-conserving and conventional system has a high VOI. It indicates that the location is potential to be developed as birdwatching sites. More importantly, the location has unique characters that enable the presence of native birds in a high quantity.

Although we do not discuss the detail of conventional agriculture, but agroforestry system is proven to protect more native biodiversity than the conventional system [9]. Our study provides important information about agroforesty system that could support the birdwatching opportunity. Therefore, conserving the agroforestry area is more recommended than broadening the area of conventional agriculture, because it could complement the needed between human and nature, including crops and wildlife. Management system is considered to be focused on conserving some specific habitats to maintain the dynamic and position of the species as the potential development of the local area.

\section{CONCLUSION}

Importance Value Index is relatively high on the Cave swiftlet and some species of birds that specialized on farmland. Preference value shows a different result for different species of birds and there is a trend that indicates the same habitat (agroforestry). Agroforestry area is more potential as an object of birdwatching compared to conventional agriculture and houses area. The interesting part of conventional agriculture and houses area is its role as an annual migration track. The high balance of VOI value in agroforestry area near the natural forest indicates that this region is recommended as a spot for birdwatching, due to the native birds.

\section{ACKNOWLEDGEMENT}

We thank to all government staff and Mr. Puji Laksana at Gubugklakah office for information support. We thank to komplangan (agroforest) farmer for their support and field assistance: Mr. Jamhali, Mr. Suji, and Mrs. Amin. We thank to Adityas Arifianto, Faldy Alifianto, Muhammad Fathoni, and Aulia Rahman El-arif for field assistance. We also appreciate review of earlier version of this manuscript by Anggun Sausan Firdaus.

\section{REFERENCES}

[1] Cordell, H. K. and N. G. Herbert. 2002. The popularity of birding is still growing. Birding 34, 54-59.

[2] Kerlinger, P. and J. Brett. 1995. Hawk Mountain sanctuary: a case study of birder visitation and birding economics. In: Knight, R. L. and K. J. Gutzwiller (Eds). Wildlife and recreationists: coexistence through mana- 
gement and research. Island Press. Washington.

[3] Munn, C.A. 1992. Macaw biology and ecotourism, or 'When a bird in the bush is worth two in the hand'. In: Beissinger, S. R. and N. F. R. Snyder (Eds.). New world Parrots in crisis: solutions from conservation biology. Smithsonian Institution Press. Washington.

[4] Eaton, J. A., C. R. Shepherd, F. E. Rheindt, J. B. C. Harris, B. van Balen, D. S. Wilcove and N. J. Collar. 2015. Trade-driven extinctions and near-extinctions of Avian Taxa in Sundaic Indonesia. Forktail 31, 1-12.

[5] Morante-Filho, J. C., D. Faria, E. MarianoNeto and J. Rhodes. 2015. Birds in anthropogenic landscapes: the responses of ecological groups to forest loss in the Brazilian Atlantic Forest. PLOS ONE 10(6), e0128923.

[6] Tryjanowski, P., T. H. Sparks, S. Kuz'niak, P. Czechowski and L. Jerzak. 2013. Bird migration advances more strongly in urban environments. PLOS ONE 8(5), e63482.

[7] Dunn, J. C., K. C. Hamer and T. G. Benton. 2015. Anthropogenically-mediated density dependence in a declining farmland bird. PLOS ONE 10(10), e0139492.

[8] Hakim, L. 2014. Etnobotani dan manajemen kebun-pekarangan rumah: ketahanan pangan, kesehatan dan agrowisata. Selaras. Malang.

[9] de Foresta, H., A. Kusworo, G. Michon and W. A. Djatmiko. 2000. Ketika kebun berupa hutan - Agroforest khas IndonesiaSumbangan masyarakat bagi pembangunan berkelanjutan. International Centre for Research in Agroforestry. Bogor.

[10] Arlt, D., P. Forslund, T. Jeppsson and T. Pa"rt. 2008. Habitat-Specific Population Growth of a Farmland Bird. PLOS ONE 3(8), e3006.

[11] Guilherme, J. L. and M. H. Pereira. 2013. Adaptation of bird communities to farmland abandonment in a mountain landscape. PLOS ONE 8(9), e73619.

[12] Hernandez, S. M., B. J. Mattsson, V. E. Peters, R. J. Cooper and C. R. Carroll. 2013. Coffee agroforests remain beneficial for neotropical bird community conservation across seasons. PLoS ONE 8(9), e65101.

[13] Hostetler, M. E. and M. B. Main. 2000 Transect method for surveying birds. In: Florida monitoring program. IFAS Extension. Florida.
[14] Republic of Indonesia. 1999. Government Regulation No. 7, 1999. Supplementary on Preservation of Plants and Animals Species.

[15] IUCN. 2016. The IUCN Red List of threatened species 2016. Available at: http://IUCNredlist.org

[16] CITES. 2017. Convention on international trade in endangered species of Wild Fauna and Flora (CITES). Available at: http://cites.org.

[17] Mackinnon, J., K. Phillipps, B. van Balen. 2010. Burung-burung di Sumatera, Jawa, Bali, dan Kalimantan. Burung Indonesia. Bogor.

[18] Kerlinger, P. 1989. Flight strategies of migrating hawks. University of Chicago Press. Chicago.

[19] Chantler, P. and G. Driessens. 2010. Swifts: a guide to the Swifts and Treeswifts of the world. Christopher Helm Publishers. London.

[20] Ayat, A. 2011. Burung-burung Agroforest di Sumatera. World Agroforestry Centre ICRAF, SEA. Bogor.

[21] Payakkhabut, S. 2012. Vocal communication in Sooty-headed Bulbul: Pycnonotus aurigaster. International Scholarly and Scientific Research and Innovation 6(4), 140-145.

[22] Frascaroli, F. 2013. Sacred sites for the conservation of biodiversity. University of Zurich, Faculty of Science. Zurich.

[23] Teillard, F., F. Jiguet and M. Tichit. 2015. The response of farmland bird communities to agricultural intensity as influenced by its spatial aggregation. PLOS ONE 10(3), e0119674.

[24] Hansell, M. 2005. Animal architecture. Oxford University Press. New York.

[25] Chamberlain, D. E., R. J. Fuller, R. G. H. Bunce, J. C. Duckworth and M. Shrubb. 2000. Changes in the abundance of farmland birds in relation to the timing of agricultural intensification in England and Wales. Journal of Applied Ecology 37, 771788.

[26] Jones, D. N. and R. Buckley. 2001. Birdwatching tourism in Australia. Wildlife tourism research report series no. 10 , status assessment of wildlife tourism in Australia Series. National Library of Australia. Australia. 
Supplementary 1. Detail Information of Bird Species

\begin{tabular}{|c|c|c|c|c|c|c|c|c|c|c|c|c|}
\hline No & Famili & English & Scientific & Code & Total in 5 location & Law $^{1}$ & IUCN $^{2}$ & CITES $^{3}$ & Endemic $^{4}$ & Frequency & vol & INP \\
\hline 1 & Accipitridae & Black Eagle & Ictinaetus malaiensis & $\mathrm{BE}$ & 21 & 1.2 & LC & 2 & & 1 & 1 & 0.035854 \\
\hline 2 & Accipitridae & Chinese Sparrowhawk & Accipiter soloensis & CS & 86 & 1.2 & LC & 2 & & 0.4 & 0.4 & 0.034854 \\
\hline 3 & Accipitridae & Crested serpent eagle & Spilornis cheela & CsE & 13 & 1.2 & LC & 2 & & 0.6 & 0.6 & 0.021618 \\
\hline 4 & Accipitridae & Japanese sparrowhawk & Accipiter gularis & JS & 15 & 1.2 & LC & 2 & & 0.4 & 0.4 & 0.016086 \\
\hline 5 & Accipitridae & Crested honey buzzard & Pernis ptilorhynchus & $\mathrm{ChB}$ & 7 & 1.2 & LC & 2 & & 0.4 & 0.4 & 0.013972 \\
\hline 6 & Accipitridae & Javan-hawk Eagle & Nisaetus bartelsi & JhE & 3 & 1.2 & EN & 2 & Java & 0.4 & 0.4 & 0.012914 \\
\hline 7 & Aegithinidae & Common lora & Aegithina tiphia & $\mathrm{Cl}$ & 5 & & LC & & & 0.2 & 0.2 & 0.007382 \\
\hline 8 & Alcedinidae & Collared Kingfisher & Todiramphus chloris & CK & 85 & 2 & LC & & & 1 & 1 & 0.052772 \\
\hline 9 & Apodidae & Cave Swiftlet & Collocalia linchi & $\mathrm{CSw}$ & 1110 & & LC & & & 1 & 1 & 0.323721 \\
\hline 10 & Apodidae & Pacific swift & Apus pacificus & PS & 11 & & LC & & & 0.6 & 0.6 & 0.02109 \\
\hline 11 & Apodidae & Edible-nest Swiftlet & Aerodramus fuciphagus & EnS & 3 & & LC & & & 0.2 & 0.2 & 0.006854 \\
\hline 12 & Campephagidae & Small Minivet & Pericrocotus cinnamomeus & SmM & 48 & & LC & & & 0.6 & 0.6 & 0.03087 \\
\hline 13 & Campephagidae & Sunda Minivet & Pericrocotus miniatus & SM & 23 & & LC & & Sumatra \& Java & 0.4 & 0.4 & 0.018201 \\
\hline 14 & Campephagidae & Pied triller & Lalage nigra & PT & 12 & & LC & & & 0.4 & 0.4 & 0.015293 \\
\hline 15 & Campephagidae & Sunda Cuckoshrike & Coracina larvata & SC & 22 & & LC & & & 0.2 & 0.2 & 0.011876 \\
\hline 16 & Cettidae & Mountain Tailorbird & Phyllergates cuculatus & MT & 1 & & LC & & & 0.2 & 0.2 & 0.006325 \\
\hline 17 & Cisticolidae & Brown Prinia & Prinia poluchroa & $\mathrm{BP}$ & 233 & & LC & & & 0.8 & 0.8 & 0.085834 \\
\hline 18 & Cisticolidae & Olive-backed tailorbird & Orthotomus sepium & ObT & 62 & & LC & & Java\&Bali & 1 & 1 & 0.046692 \\
\hline 19 & Cisticolidae & Common Tailorbird & Orthotomus sutorius & CT & 10 & & LC & & & 0.8 & 0.8 & 0.026886 \\
\hline 20 & Cisticolidae & Bar-winged Prinia & Prinia familiaris & BwP & 4 & & LC & & Indonesia & 0.4 & 0.4 & 0.013179 \\
\hline 21 & Cisticolidae & Plain prinia & Prinia inornata & PP & 8 & & LC & & & 0.2 & 0.2 & 0.008175 \\
\hline 22 & Columbidae & Spotted Dove & Spilopelia chinensis & SD & 41 & & LC & & & 0.8 & 0.8 & 0.03508 \\
\hline 23 & Columbidae & Ruddy Cuckoo-dove & Macropygia emiliana & $\mathrm{RCd}$ & 9 & & LC & & & 0.6 & 0.6 & 0.020561 \\
\hline 24 & Columbidae & Pink-headed fruit dove & Ptilinopus porphyreus & $\mathrm{PhFd}$ & 9 & & LC & & Indonesia & 0.4 & 0.4 & 0.0145 \\
\hline 25 & Columbidae & Grey-cheeked Green-pigeon & Treron griseicauda & GcGP & 2 & & LC & & & 0.2 & 0.2 & 0.006589 \\
\hline 26 & Columbidae & Dark-backed Imperial Pigeon & Ducula lacernulata & Dblp & 1 & & LC & & Indonesia & 0.2 & 0.2 & 0.006325 \\
\hline 27 & Cuculidae & Rusty-breasted cuckoo & Cacomantis sepulcralis & $\mathrm{RbC}$ & 36 & & LC & & & 1 & 1 & 0.039819 \\
\hline
\end{tabular}




\begin{tabular}{|c|c|c|c|c|c|c|c|c|c|c|c|c|}
\hline No & Famili & English & Scientific & Code & Total in 5 location & Law $^{1}$ & IUCN $^{2}$ & CITES $^{3}$ & Endemic $^{4}$ & Frequency & Vol & INP \\
\hline 28 & Cuculidae & Plaintive cuckoo & Cacomantis merulinus & PC & 21 & & LC & & & 1 & 1 & 0.035854 \\
\hline 29 & Cuculidae & Chestnut-breasted malkoha & Phaenicophaeus curvirostris & $\mathrm{CbM}$ & 3 & & LC & & & 0.4 & 0.4 & 0.012914 \\
\hline 30 & Cuculidae & Oriental Cuckoo & Cuculus saturatus & OC & 12 & & $\mathrm{LC}$ & & & 0.2 & 0.2 & 0.009233 \\
\hline 31 & Dicaeidae & Scarlet-headed flowerpecker & Dicaeum trochileum & ShF & 9 & & LC & & Indonesia & 0.4 & 0.4 & 0.0145 \\
\hline 32 & Dicaeidae & Blood-breasted Flowerpecker & Dicaeum sanguinolentum & $\mathrm{BbF}$ & 8 & & LC & & Indonesia & 0.4 & 0.4 & 0.014236 \\
\hline 33 & Dicruridae & Ashy Drongo & Dicrurus leucophaeus & $A D$ & 1 & & LC & & & 0.2 & 0.2 & 0.006325 \\
\hline 34 & Estrildidae & Javan Munia & Lonchura leucogastroides & $J M$ & 95 & & $\mathrm{LC}$ & & Indonesia & 1 & 1 & 0.055415 \\
\hline 35 & Estrildidae & Scally-breasted Munia & Lonchura punctulata & $\mathrm{SbM}$ & 8 & & LC & & & 0.2 & 0.2 & 0.008175 \\
\hline 36 & Hirundinidae & Pacific Swallow & Hirundo tahitica & PS & 99 & & LC & & & 0.6 & 0.6 & 0.044352 \\
\hline 37 & Hirundinidae & Striated Swallow & Hirundo striolata & SS & 48 & & LC & & & 0.4 & 0.4 & 0.02481 \\
\hline 38 & Hirundinidae & Barn Swallow & Hirundo rustica & BS & 4 & & LC & & & 0.2 & 0.2 & 0.007118 \\
\hline 39 & Laniidae & Long-tailed Shrike & Lanius schach & LtS & 16 & & LC & & & 0.6 & 0.6 & 0.022411 \\
\hline 40 & Locustellidae & Striated grassbird & Megalurus palustris & SG & 94 & & LC & & & 1 & 1 & 0.055151 \\
\hline 41 & Megalaimidae & Flame-fronted barbet & Psilopogon armillaris & $\mathrm{FfB}$ & 69 & & LC & & Indonesia & 0.4 & 0.4 & 0.030361 \\
\hline 42 & Megalaimidae & Black -banded Barbet & Psilopogon javensis & $\mathrm{BbB}$ & 37 & 1.2 & NT & & Java \& Bali & 0.4 & 0.4 & 0.021902 \\
\hline 43 & Megalaimidae & Coppersmith Barbet & Psilopogon haemacephalus & $\mathrm{CB}$ & 5 & & LC & & & 0.2 & 0.2 & 0.007382 \\
\hline 44 & Muscicapidae & Lesser Shortwing & Brachypteryx leucophrys & LS & 47 & & LC & & & 0.6 & 0.6 & 0.030606 \\
\hline 45 & Muscicapidae & Sunda Forktail & Enicurus velatus & SF & 12 & & LC & & Indonesia & 0.6 & 0.6 & 0.021354 \\
\hline 46 & Muscicapidae & Javan whistling thrush & Myophonus glaucinus & JwT & 6 & & LC & & Java \& Bali & 0.2 & 0.2 & 0.007647 \\
\hline 47 & Muscicapidae & Little pied flycatcher & Ficedula westermanni & LpF & 4 & & LC & & & 0.2 & 0.2 & 0.007118 \\
\hline 48 & Muscicapidae & Snowy-browed flycatcher & Ficedula hyperythra & $\mathrm{SbF}$ & 2 & & LC & & & 0.2 & 0.2 & 0.006589 \\
\hline 49 & Nectariniidae & Olive-backed Sunbird & Cinnyris jugularis & ObS & 53 & 1.2 & LC & & & 1 & 1 & 0.044313 \\
\hline 50 & Nectariniidae & Streaky-breasted spiderhunter & Arachnothera affinis & $\mathrm{SbS}$ & 1 & 1.2 & LC & & & 0.2 & 0.2 & 0.006325 \\
\hline 51 & Paridae & Great Tit & Parus major & GT & 22 & & LC & & & 0.6 & 0.6 & 0.023997 \\
\hline 52 & Passeridae & Eurasian tree sparrow & Passer montanus & EtS & 284 & & LC & & & 1 & 1 & 0.105376 \\
\hline 53 & Pellorneidae & Horsfield's Babbler & Malacocincla sepiaria & $\mathrm{HB}$ & 2 & & LC & & & 0.2 & 0.2 & 0.006589 \\
\hline 54 & Phasianidae & Green junglefowl & Gallus varius & GJ & 5 & & LC & & Indonesia & 0.6 & 0.6 & 0.019504 \\
\hline
\end{tabular}




\begin{tabular}{|c|c|c|c|c|c|c|c|c|c|c|c|c|}
\hline No & Famili & English & Scientific & Code & Total in 5 location & Law $^{1}$ & IUCN $^{2}$ & CITES $^{3}$ & Endemic $^{4}$ & Frequency & Vol & INP \\
\hline 55 & Phylloscopidae & Mountain Leaf Warbler & Phylloscopus trivirgatus & MIW & 20 & & LC & & & 0.2 & 0.2 & 0.011347 \\
\hline 56 & Picidae & Fulvous-breasted Woodpecker & Dendrocopos macei & FbW & 23 & & LC & & & 1 & 1 & 0.036383 \\
\hline 57 & Pittidae & Banded Pitta & Hydrornis guajana & $\mathrm{BP}$ & 1 & 1.2 & LC & 2 & Indonesia & 0.2 & 0.2 & 0.006325 \\
\hline 58 & Podargidae & Javan Frogmouth & Batrachostomus javensis & $\mathrm{JF}$ & 1 & & LC & & & 0.2 & 0.2 & 0.006325 \\
\hline 59 & Psittacullidae & Yellow-throated hanging parrot & Loriculus pusillus & $\mathrm{YtHp}$ & 3 & & NT & 2 & Java \& Bali & 0.4 & 0.4 & 0.012914 \\
\hline 60 & Pycnonotidae & Sooty-headed bulbul & Pycnonotus aurigaster & ShB & 820 & & LC & & & 1 & 1 & 0.247062 \\
\hline 61 & Pycnonotidae & Yellow-vented Bulbul & Pycnonotus goiavier & YvB & 41 & & LC & & & 0.6 & 0.6 & 0.02902 \\
\hline 62 & Sittidae & Blue Nuthach & Sitta azurea & $\mathrm{BN}$ & 2 & & LC & & & 0.2 & 0.2 & 0.006589 \\
\hline 63 & Strigidae & Sunda-scops Owl & Otus lempiji & SsO & 2 & & LC & 2 & & 0.4 & 0.4 & 0.01265 \\
\hline 64 & Sturnidae & Short-tailed Starling & Aplonis minor & StS & 13 & & LC & & & 0.2 & 0.2 & 0.009497 \\
\hline 65 & Timallidae & Crescent-chested Babbler & Stachyris melanothorax & $\mathrm{CcB}$ & 4 & 1.2 & LC & & Indonesia & 0.4 & 0.4 & 0.013179 \\
\hline 66 & Turdidae & Scally Thrush & Zoothera dauma & ST & 2 & & LC & & & 0.2 & 0.2 & 0.006589 \\
\hline 67 & Turnicidae & Barred Buttonquail & Turnix suscitator & BB & 2 & & LC & & & 0.4 & 0.4 & 0.01265 \\
\hline 68 & Zosteropidae & Oriental white-eye & Zosterops palpebrosus & Owe & 2 & & LC & & & 0.2 & 0.2 & 0.006589 \\
\hline
\end{tabular}

Notes: ${ }^{1}$ Law [14], ${ }^{2}$ IUCN status [15] ${ }^{3} \mathrm{CITES}$ status [16], ${ }^{4}$ Endemic status [17] 